\title{
INTERLINGUAL HOMONYMS OF POLYSEMIC ORIGIN IN RELATED LANGUAGES
}

\section{Introduction}

The topic of interlingual homonyms is a linguistic phenomenon which very frequently preoccupies both academics and foreignlanguage translators and teachers. From the perspective of didactics, interlingual homonyms or false friends are words that are similar in spelling and/or pronunciation in two languages but have different meanings. A common mistake that beginning students of foreign languages make is the assumption that a word that looks similar to the one they know will have the same meaning.

It is crucial to supplement the existence and functioning of homonymic elements also by other linguistic criteria and phenomena such as word-formation features, the criterion of synonymic lexemes, stylistic aspects and the place of homonyms both in paradigmatic and syntagmatic hierarchies. Our primary role is to analyse the mutual relationships of interlinguistic homonyms from the point of view of polysemy and monosemy in the compared languages. At the beginning we briefly define the notion of homonyms in the sphere of semantics; we point out that their theoretical and terminological specification is not unified in linguistic literature.

\section{Homonymy and polysemy}

Slavic and Anglo-Saxon linguistic literatures offer tens of various definitions of homonymy and also theoretical disputations concerning boundaries between homonymy and polysemy. At the same time, the disunity of lexicographical elaboration of possible homonyms illustrates that the boundary is not impervious.
Within the context of Slovak linguistics, Findra contributed to the research of differences between these two categories. If polysemy and homonymy should stay individual (bordered lexicological) categories then it is crucial to arise from the view according to which the origin (the way of creation) of two or more identically sounding naming units having a different meaning is the most verifiable criterion when setting boundaries between them [1].

In addition to this, Findra evaluates homonyms as two words whose phonetic form is the result of chance [1]. Each of the two homonymic words denotes a different (individual) object, phenomenon, feature or process. On the other hand, analysing polysemy we proceed from one, basic, initial or primary meaning. The other meanings of a polysemic naming unit originate usually by a metaphorical way so that the original (primary) meaning is divided into several individual secondary meanings.

Considering this, polysemy and homonymy as system lexicographical categories, are in the relationship of similarity and difference mostly with synonymy and antonymy. Complex mutual connections among words of lexicon and their meanings are reflected within the relationships and at the same time they demonstrate the structural nature of the language layer which also creates a mutually interconditioned and logically correlated system of elements.

Out of the Slavic linguistics, the Bulgarian lexicology pays a closer attention to the differentiation of polysemy and homonymy [2]. It is possible to use four methods in order to define differences between polysemy and homonymy:

1. Semantic - it is based on the usage of a word in a context - it is the method applied also within the Slovak lexicology,

\footnotetext{
* Marta Lackova, Eva Lelakova

Department of English Language and Literature, Faculty of Humanities, University of Zilina, Slovakia

E-mail: marta.lackova@fhv.uniza.sk
} 
2. Synonymic - it utilizes the creation of new synonymic rows; when it is not possible to use a synonym from one synonymic row in another synonymic row, we talk about homonymy,

3. Word-formation - homonymy is defined by its capacity to create new words and

4. Grammatical - homonymy might be identified as a condition when each word has its own paradigm which is different from the paradigms of other words.

Russian linguistics in particular determines the following basic attitudes to the interpretation of lexical homonymy and polysemy [3]:

The first attitude is based on the recognition of both monosemic and polysemic words. Three procedures are applied in order to define differences between homonymy and polysemy:

1. Homonyms are only the identically sounding words which originally had a different form and they were mutually equal from the point of view of phonetics or orthography under the influence of various reasons,

2. Homonyms are words with different etymology but with a corresponding phonetic form and

3. Homonyms originate when the meanings of polysemic words digressed so much that new words have the conditions to originate.

The second attitude is connected with the recognition of only monosemic words existence; each of them is associated only with one denotate.

The studied issue is closely interconnected with diachronic aspects. The relation of polysemy and homonymy changes during the language development. This state is determined by the dialectic unity of content and form of a word as a linguistic sign. During the development of the language semantic system there are two processes in the direction from polysemy to homonymy and vice versa.

Changes in the meanings of words are determined by numerous reasons both of linguistic and extralinguistic characters. Psychological and social aspects like prejudices or stereotypes as fixed attitudes aimed at certain objects or phenomena with which one does not have any experience are counted among them [4].

Generally speaking, the following processes are observed when taking into account the origin and etymology of homonyms [5]:

1. Taking over of foreign words,

2. Calques,

3. Word-formation processes and

4. Semantic development of a word - splitting of polysemy (historical, homogenous homonymy).

Homonymy from split polysemy is considered to be the most common source of intralingual homonyms [6]. These homonyms appear when their meaning digress to such an extent that they lose the relationship which had connected them. The relationship of development is becoming illegible from the synchronic point of view and completely independent lexical units originate. This type is characterized as a homogenous type of homonymy as it is the consequence of the semantic development of a lexeme. In order to differentiate homogenous homonyms from a polysemic lexeme a complex semantic and word-formation analysis is essential.

From the point of view of semantics, homonymy appears when:

1. Originally one word is decomposed into two or three meanings,

2. Originally one word is decomposed into two or three lexemes via a semantic change of its base and by a different, but in its result the identical derivation and

3. Two from their origin different native words merge during the language development [7].

Only the type of lexical polysemy which Dolnik calls the indirect (mediated) polysemy might turn into homonymy [7].

Homonymy represents the limit of a semantic modification of a word and a contextual influence on one of its meanings. The semantic modification of a word is a potential process of its homonymization. It is necessary to add that the potential homonymization of a word is acceptable with specific types of a semantic modification so only a certain type of lexical polysemy might lead to homonymy.

Furthermore, homonymy becomes the limit of semantic modification of a word exclusively at indirect polysemy. The difference between the direct and indirect polysemy lies in the extent of affinity of the original and derived meanings.

With direct polysemy the higher extent of semantic affinity is reflected in the fact that a common, connecting element is a constituent of both the meanings. With contrasting the indirect polysemy, the common element is only an implicated element of the original meaning. The weaker the implicated relationship between the connecting element and the original, or derived meaning is, the lower the extent of affinity between the original and derived meanings is - the more semantic modification is approaching the limits of homonymy.

Studying the last type of homonyms it is found out when and how the semantic decomposition of the word is realized; it is the object of diachronic lexicology. Homonyms, as the result of this process, are evaluated as a synchronic dynamic lexico-semantic phenomenon. Thus they become the subject of synchronic lexicology.

\section{The concept of interlinguistic homonyms of polysemic origin}

While contrasting two or more typologically close or diverse languages, interlinguistic homonymy of polysemic words represents a specific instance of the homonymy and a constant source of interference. 
Loan words represent a frequent source of partial or complete interlingual homonyms (i.e. false friends) in three ways [8]:

1. In the target language loan words might be restricted only to one of possible meanings of a polysemic word from the source language,

2. Loan words might develop polysemies which are missing in the source language, and

3. The meaning of loan words might digress form the meaning/meanings of the source language because have been used metaphorically. We observe the above mentioned semantic processes in these examples (i.e. a monosemic word along with polysemies):

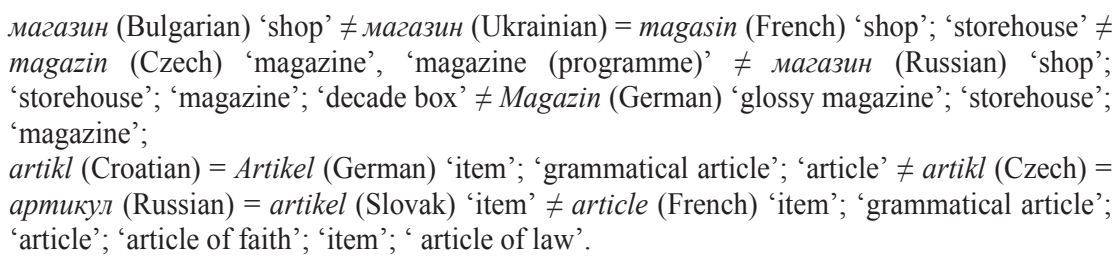

Lotko provides an extensive classification of interlinguistic homonyms which operate in Slavic languages [8]. He analyses numerous aspects of these lexical units (grammar, pronunciation, origin, and stylistics) but for the needs of our research we concentrate on their semantic subgroups. False friends are equally as other lexical units either monosemic or polysemic. Polysemic false friends are divided into fully false (all the meanings are different) and partially false (some meanings are the same and the others are different).

False friends might be not only polysemic but also to a lesser degree homonymic. Usually we deal with homonymy in one of the compared languages. Homonymic words are either of the identical origin or they come from various languages. Khutsishvili introduces several types of semantic relations in the sphere of interlingual homonyms [3]:

1. Relations of semantic exclusion - semantic disjunction and

2. Relations of semantic identity - semantic inclusion or intersection.

For the purposes of our research these two groups provide the ground for the following correspondences:

a) a monosemic word corresponds to a polysemic word (the most frequent combination; either semantic inclusion or exclusion are present):

jar (Slovenian) 'spring'; 'angry' $\neq$ jary (Ĉzech) 'fresh';

знак (Bulgarian) 'sign' $\neq$ znak (Czech) 'feature'; 'symptom'; 'sign'; 'symbol';

'backstroke';

frkati (Slovenian) 'to run around'; 'to flip'; 'to lock' $\neq$ frkat (Czech) 'to snort'; to huff';

bànkèt (Croatian) 'banquet'; 'bench' $\neq$ banket (Czech) 'banquet';

kúkati (Slovenian) 'to cuckoo'; 'to be peeing out'; 'to stick out' $\neq$ kukat (Czech)

'to cuckoo';

будова (Belorussian) 'building'; 'structure' $\neq$ budova (Czech) 'building'.

b) a polysemic word corresponds to a polysemic word (there must be at least one differentiating seme; couples where the "falseness" is manifested only at some meanings of polysemic lexical units and other meanings of word counterparts correspond mutually):

jadrn (Slovenian) 'fast'; 'sailing' $\neq$ jadrny (Czech) 'earthy'; 'apt';

kaliti (Slovenian) 'to make cloudy'; 'to spoil'; 'to quench'; 'to germinate' $\neq$ kalit

(Czech) 'to make cloudy'; 'to spoil'; 'to quench'.

One of the reasons of their existence is that there are not corresponding polysemic words according to the number of lexicosemantic variants:

ljubiti (Croatian) 'to love'; 'to like'; 'to kiss' ₹ любить (Russian) 'to love'; 'to like'.

In addition to this, the examples below illustrate the employment of metaphorical meanings in the framework of this relationship:

hlâd (Croatian) 'shadow' $\neq$ hlad (Czech) 'hunger'; 'lack of food'; ' cold';

'heartlessness'; 'desire';

nop (Bulgarian) 'polecat'; 'to stink like a skunk' metaphor, jargon $\neq$ por (Czech)

'leek'; 'pore';

завет (Bulgarian) 'lee'; metaphor; 'message' fzavět' (Czech) 'testament';

вp bx (Bulgarian) 'top'; 'tongue tip; 'crest' metaphor; 'authority' metaphor $\neq$ vrch

(Czech) 'hill'; 'hillside'; 'top';

amàzōnka (Croatian) 'Amazon' mythological; 'woman rider'; 'Amazon'(virago)

metaphor 'long woman shirt for riding' \# Amazonka (Czech) 'Amazon'

mythological; 'Amazon'(virago) metaphor;

mrâk (Croatian) 'darkness'; 'dark night'; 'ignorance' metaphor $\neq$ mrak (Czech)

'cloud'; 'mass'; 
nápoj (Croatian) 'drink' bookish; 'pigswill' metaphor; 'swill’ $\neq$ nápoj (Czech)

'drink';

zmija (Croatian) 'snake'; 'Ophidia serpents'; 'harpy' metaphor $\neq$ zmije (Czech)

'viper'; 'harpy' metaphor $\neq$ змия (Bulgarian) 'snake'; 'harpy' metaphor.

c) a monosemic word corresponds to a monosemic word (semantic exclusion - a couple of words semantically completely different):

алей (Belorussian) 'vegetable oil' $\neq$ alej (Czech) 'lane';

vëš (Croatian) 'clothes' $\neq$ veš (Czech) 'lice’;

моторка (Ukrainian) 'motor boat' $\neq$ motorka (Czech) 'motor cycle'.

Moreover, regular semantic correspondences do not appear within languages which belong to the same branch of the Slavic language family (east Slavic languages, west Slavic languages): вид (Ukrainian) 'kind, type'; 'face'; 'look'; 'branch'; $\neq$ вид (Russian) 'type, kind'; 'grammatical aspect' $\neq$ vid (Czech) 'there is no trace of him'; 'grammatical aspect' $\neq$ vid (Slovak) 'grammatical aspect'; 'there is no trace of him'.

\section{Linguistic characteristics of interlinguistic homonyms of polysemic origin}

Interlingual homonyms of polysemic origin are further described from the point of view of the phonetic, orthographic, morphological and stylistics aspects. The following lexical units demonstrate certain phonetic and orthographic peculiarities on the base of which they are traditionally divided into the following subgroups [5]:

1. Phonetic-graphic homonyms - the graphic and phonetic forms of the lexical units are the same; there exist differences in their meaning:

завод (Macedonian) 'factory'; 'bureau, institution’ $\neq 3$ завод (Russian) 'factory’;

2. Phonetic homonyms - the lexical units correspond to each other from the point of view of phonetics but there appear differences in their graphitic form:

булка $($ Belorussian $)=$ butka $($ Polish $)=$ булка $($ Russian) 'baked yeast dumpling' $\neq$

булка (Bulgarian) 'bride'; 'young woman' $\neq$ bulka (Czech) 'swelling'; 'bull';

булка (Ukrainian) 'baked yeast dumpling' $\neq$ булька (Ukrainian) 'bubble' $\neq$ булка

(Ukrainian) 'bride' obsolete (homonyms also in Ukrainian);

3. Graphic homonyms - the lexical units correspond to each other from the point of view of graphics but there appear differences in their phonetic form:

листопад (Russian) 'falling of leaves' $\neq$ листопад (Ukrainian) 'falling of leaves';

'November' (differences in the pronunciation of vowels $u$ and $o$ ).

The formal criterion determining the forms agreement which is necessary for setting the boundaries between individual types of lexical units of homonymic character has to take into account the agreement principle in conformity with which we do not find relevant regular graphic, phonetic and morphological differences.

In other words, when conceiving homonymic couples and rows orthographic peculiarities of individual compared languages do not play the crucial role while Roman and Cyrillic alphabets do not represent any obstacle when analysing semantics of the studied lexical units. At the same time, we have to count with natural alternations of consonants and vowels:

gŕd (Slovenian) 'ugly', 'disagreeable', 'nasty' expressive $\neq$ hrdý (Czech) 'proud',

'self-confident';

лицѐ (Bulgarian) 'face'; 'facade'; 'expression'; 'person' \# lice (Czech) 'face’ book. \#

личо (Russian) 'face'; 'profile, plasticity, character'; 'person'; 'cheek'; 'person'

linguistic $\neq$ lice (Slovak) 'cheek'.

Morphological features of interlingual homonyms copy general principles of grammatical systems functioning of individual Slavic languages and at the same time, they highlight the differences between them. On the one hand, the languages show corresponding features (lexical units with the same grammatical paradigm), on the other hand, we observe differences in the grammatical categories of interlingual homonyms:

a) number of nouns:

бои (Bulgarian) 'fight' (only singular); 'stature' $\neq$ boj (Czech) 'fight'; 'struggle';

вкус (Bulgarian) 'taste' (only singular); 'flavor' (only singular); 'style'; 'elegance' $\neq$ vkus (Czech) 'taste'; 'style';

высочина (Bulgarian) 'pitch of tone' (only plural); 'altitude' geometrical; 'hill'; 'height' $\neq$ vkus (Czech) 'highlands'; 
b) gender of nouns:

закуेска (Ukrainian) 'starter'; 'bite'; 'breakfast'; 'snack'; 'dessert' feminine $\neq$ закуска

(Russian) 'bite' feminine $\neq$ zákuska (Croatian) 'dessert'; 'refreshment' feminine $\neq$

zákusek (Czech) 'dessert' masculine.

Generally, homonyms which operate on interlinguistic level have become members of open word classes (marginally pronouns and adverbs) but the studied homonyms are noted exclusively within:

a) nouns:

лихва (Bulgarian) 'interest'; 'charge' $\neq$ lichva (Czech) 'usury;

кадър (Bulgarian) 'cadres' (either singular or plural); 'staff'; 'core group'; 'reserves';

'shot' $\neq$ kadr (Czech) 'core group'; 'cadres';

образеи (Bulgarian) 'model’; 'sample'; 'specimen’; $\neq$ obrazec (Czech) 'figure’;

b) adjectives:

kŕmen (Slovenian) 'fodder'; 'rear' $\neq$ krmný (Czech) 'fodder'; 'for fattening';

obraten (Slovenian) 'opposite'; 'company' $\neq$ obratný (Czech) 'skillful'; 'clever';

konieczny (Polish) 'necessary $\neq$ konečný (Czech) 'final, bounded, definite’;

c) verbs:

moriti (Slovenian) 'to kill'; 'to exhaust'; 'to torment' $\neq$ morit (Czech) 'to torment';

'to annoy'; 'to stain';

dotírati (Slovenian) 'to subsidize'; 'to bring, to drive'; $\neq$ dotírat (Czech) 'to pester',

'to badger', 'to harass', 'to bug';

baviti (Slovenian) 'to occupy' $\neq$ bavit (Czech) 'to talk to sb', 'to have good fun'.

Semantic features of the analysed lexical units represent the essence of their functioning and the interference they cause. The reasons of the origin of semantic differences within the studied issue are to be found - except for extralinguistic features - also in their etymology. The number and role of possible sources of interlinguistic homonyms in a specific group of languages are different and they are determined by genetic and historical language contexts.

International lexis represents a special layer within the studied issue. Recently the words of English origin which have penetrated into contemporary Slavic languages [9] have acquired an important position within the context. The typology of differences in the field of international lexis is to be divided into three subgroups [3]:

1. Semantic differences - connected with the fact that a word might have a more general meaning in one language and a more specific meaning in the other one; a word is monosemic in one language and polysemic in the other one,

2. Historical differences and

3. Functional and stylistical differences - the group of meaning of international origin in one language might be of neutral nature and in the other language it might belong to stylistically marked words. These discrepancies are connected with the accessibility of the word usage predominantly or marginally in certain functional styles - the phenomenon is very common in Slavic languages:

dóza $($ Croatian $)=$ доз $a$ (Ukrainian) 'dose' $\neq$ dóza $($ Czech) 'decorative case' $\neq$ doze

(Czech) 'dose of medicine'; 'medicine' $\neq$ Dose (German) 'little box'; 'cigarette case';

'tin'; 'dose of medicine' colloquial; 'socket' technical, colloquial.

From the perspective of stylistics, the above mentioned lexical units find their realization within several stylistic layers both in literary and non-literary forms of language (see Table 1 and Table 2):

Interlingual homonymy in literary forms of language
\begin{tabular}{|l|l|}
\hline stylistically neutral lexical units & $\begin{array}{l}\text { kŕč́ti (Slovenian) 'to shrink'; 'to cause } \\
\text { cramps'; 'to stamp'; 'to clear fell'; } \neq \text { krčit } \\
\text { (Czech) 'to furrow'; 'to crease; 'to huddle; } \\
\text { gradíti (Slovenian) 'to build'; 'to create'; 'to } \\
\text { divide'; 'to place' = hradit (Czech) 'to } \\
\text { enclose'; 'to pay'; }\end{array}$ \\
\hline $\begin{array}{l}\text { a stylistically neutral lexical unit in } \\
\text { opposition to a term } \\
\text { f množina (Slovak) = množina (Czech) 'set } \\
\text { of elements determined in a certain way'; } \\
\text { 'set of numbers'; }\end{array}$ \\
\hline $\begin{array}{l}\text { a stylistically neutral lexical unit in } \\
\text { opposition to a bookish word }\end{array}$ & $\begin{array}{l}\text { vekovit (Slovenian) 'imperishable'; 'eternal' } \\
\text { fvěkovitý (Czech) 'age-old' }\end{array}$ \\
\hline
\end{tabular}




\section{COMMNICOIIONS}

\begin{tabular}{|c|c|}
\hline $\begin{array}{l}\text { a stylistically neutral lexical unit in } \\
\text { opposition to an obsolete word }\end{array}$ & $\begin{array}{l}\text { diven díven (Slovenian) 'beautiful' obsolete } \\
\neq \text { divný (Czech) 'strange', 'suspicious', } \\
\text { 'fishy' } \neq \text { duвный (Russian) 'beautiful'; } \\
\text { 'extraordinary' obsolete; } \\
\text { naróčen (Slovenian) 'wrist' obsolete } \neq \\
\text { náročný (Czech) 'demanding', 'sumptuous', } \\
\text { 'difficult'; }\end{array}$ \\
\hline $\begin{array}{l}\text { a stylistically neutral lexical unit in } \\
\text { opposition to a colloquial word }\end{array}$ & $\begin{array}{l}\text { pohitéti (Slovenian) 'to be in a hurry' } \neq \\
\text { pochytit (Czech) 'to catch'; 'to grasp' } \\
\text { expressive; 'pick up' colloquial; }\end{array}$ \\
\hline $\begin{array}{l}\text { a stylistically neutral lexical unit in } \\
\text { opposition to a slang word }\end{array}$ & $\begin{array}{l}\text { läska (Croatian) 'compliment' } \neq \text { laska } \\
\text { (Polish) 'stick' 'beauty' slang } \neq \text { láska } \\
\text { (Czech) 'love, beloved thing'; } \\
\text { покарання (Ukrainian) 'punishment', 'fine' } \\
\neq \text { кара (Russian) 'punishment' } \neq \text { kára } \\
\text { (Czech) 'handcart'; 'car' slang; }\end{array}$ \\
\hline $\begin{array}{l}\text { a stylistically neutral lexical unit in } \\
\text { opposition to a dialectal word }\end{array}$ & $\begin{array}{l}\text { čárka (Czech) 'short line'; 'comma'; } \\
\text { 'decimal point' } \neq \text { cârka (Croatian) } \\
\text { 'magician' dialectal; 'battle'; 'variance'; } \\
\text { čislo (Slovenian) 'prayer beads' dialectal } \neq \\
\text { číslo (Czech) 'number'; 'issue'; 'act'; 'size'; } \\
\text { 'grammatical number'; }\end{array}$ \\
\hline $\begin{array}{l}\text { a stylistically neutral lexical unit in } \\
\text { opposition to a poetic word }\end{array}$ & $\begin{array}{l}\text { szumny (Polish) 'effervescing' poetic, } \\
\text { 'extraorbitant, ostentatious' } \neq \text { šumný (Czech) } \\
\text { 'efferverscing' bookish, 'handsome, nice' } \\
\text { expressive; }\end{array}$ \\
\hline $\begin{array}{l}\text { a stylistically neutral lexical unit in } \\
\text { opposition to a vulgarism }\end{array}$ & $\begin{array}{l}\text { hlastáti (Slovenian) 'eat noisily' (animals, } \\
\text { people vulgar); 'have a desire' expressive; } \neq \\
\text { chlastat (Czech) ' drink (animals)'; 'drink } \\
\text { voraciously' = chlastat' (Slovak) 'drink } \\
\text { voraciously' expressive; }\end{array}$ \\
\hline
\end{tabular}

Some of these lexical units are false several times as they together with their special semantics and in comparison with their dialexeme in the original language can function in individual meanings with a different semantic value. It is possible to observe combinations of several stylistic layers within one homonymic row:

vážen (Slovenian) 'important, serious' obsolete; 'boastful' slang $\neq$ vážený (Czech)

'having respect' $\neq$ важный (Russian) 'important'; 'looking important' $\neq$ важен

(Bulgarian) 'important'; 'serious';

staw (Polish) 'joint' anatomic; 'water reservoir' $\neq$ stav (Czech) 'conditions'; 'stratum';

'loom';

китка (Bulgarian) 'bunch'; 'tuft', 'cluster'; 'flowers' colloquial; 'wrist' $\neq$ kytka

(Czech) 'bunch'; 'flower' regional.

Finally there exists a transition group between stylistic and semantic interlingual homonyms - formal-semantic interlingual homonyms. They demonstrate not only a diverse stylistic value of individual meanings of a polysemic word but also differences in denotation.

\section{Conclusion}

For terminological, didactic and translation practice it is crucial to realize that it is not possible to take into consideration only the meaning which is indicated by the interlingual homonym from the original language on the basis of its form but it is necessary to search also for its semantic elements in the target language.

Another aspect covers the fact that such a lexical unit might have the same meaning in several languages while the differentiating meaning appears only in one of the studied languages. At the same time, interlingual homonyms have the ability to utilize forms of the borrowed word adaptation into the target language.

The practical value of the interlingual homonyms of polysemic origin research in related and non-related languages is important for the correct understanding of contemporary fiction, films, newspaper texts, and academic and professional pieces of writing. 


\section{References}

[1] FINDRA, J.: On Functional Possibilities of Polysemy and Homonymy (in Slovak), Slovenska rec, 43, 1978, 129-139.

[2] VASILIKI, C, S.: On the Relationships of the Notions of Diaparonymy and False Friends of a Translator (in Russian), Lekticeskaja i grammaticeskaja semantika romanskych i germanskych jazykov, Kisinev, 1989, 29-37.

[3] KHUTSISHVILI, S. D.: Slavic Interlingual Homonyms (in Russian) [cit. 2014-1-15] http://old.press.tsu.ge/GEO/internet/ disertaciebi/S.Khutsishvili\%20Disertacia.pdf

[4] CABANOVA, V.: Antiprejudical Education in the Information Society, Communications - Scientific Letters of the University of Zilina, No. 2, 2007, 45-47.

[5] CSAPAK, R.: Interlingual Homonymy in Literary Slovak and Bulgarian as a Lexicological Issue (in Slovak) [cit. 2014-1-15]. http:// www.pulib.sk/elpub2/FF/ Chovanec3/pdf_doc/jazykoveda/7.pdf

[6] CERMAK, F.: Language and Linguistics (in Czech), Praha : Karolinum, 2004.

[7] DOLNIK, J.: Lexicology (in Slovak), Bratislava : Univerzita Komenskeho, 2003.

[8] LOTKO, E.: False Friends in Polish and Czech (in Czech), Olomouc : Filozoficka fakulta Univerzity Palackeho, 1987.

[9] KATRENIAKOVA, Z:: Anglicisms in Slovak from the Viewpoint of Didactic Communication (in Slovak), Banska Bystrica : Metodicke centrum, 2002. 